\title{
Effects of prolactin on conceptus survival and uterine secretory activity in pigs*
}

\author{
K. H. Young, R. R. Kraeling $\dagger$ and F. W. Bazer \\ Animal Science Department, University of Florida, Gainesville, FL 32611, USA; and \\ $\dagger$ Animal Physiology Research Unit, U.S.D.A, A.R.S., \\ Richard B. Russell Agricultural Research Center, Athens, GA 30613, USA
}

\begin{abstract}
Summary. Hypoprolactinaemia was induced by bromocriptine (CB154; $100 \mathrm{mg} /$ day) which decreased circulating prolactin by $40 \%(P<0.06)$, but did not affect conceptus survival at Day 25 when administered on Days 10-16 when compared to saline:ethanoltreated control gilts. Bromocriptine or vehicle was administered to cyclic gilts on Days 10-11, oestradiol valerate was injected on Day 11 and uterine flushings were collected on Day 12. Total recoverable protein and uteroferrin in uterine flushings were not affected by treatment. However, leucine aminopeptidase activity $(P<0.02)$ and total recoverable $\mathrm{Ca}^{2+}, \mathrm{Na}^{+}, \mathrm{K}^{+}$and $\mathrm{Cl}^{-}(P<0.05)$ were decreased in uterine flushings of gilts that received bromocriptine, suggesting that hypoprolactinaemia decreased general secretory activity of the endometrial epithelium and modulated ionic changes, respectively, in the uterine environment of pigs.

Subcutaneous administration of pig prolactin $(1 \mathrm{mg} / 12 \mathrm{~h})$ increased $(P<0.001)$ serum prolactin $4 \cdot 5$-fold. The interaction between hyperprolactinaemia and progesterone, without oestrogen, on components of uterine flushings were determined using gilts that received progesterone ( $200 \mathrm{mg} /$ day) and prolactin or saline on Days 4-14 after ovariectomy on Day 4. On Day 15, there were no differences $(P>0.05)$ in any of the uterine secretory components measured. Hyperprolactinaemia (1 mg pig prolactin on Days 6-11) enhanced overall uterine secretory response on Day 12 to oestradiol $(5 \mathrm{mg})$ administered on Day 11 compared to gilts that received $1 \mathrm{ml}$ saline on Days 6-11 of the oestrous cycle. Total recoverable protein and leucine aminopeptidase activity were greater $(P<0.05)$ for oestradiol-treated gilts, but effects of prolactin were not significant. Total recoverable glucose $(P<0.01)$, PGF- $2 \alpha(P<0.02)$, uteroferrin $(P<0.01)$ and specific activity of uteroferrin $(P<0.001)$ were increased by prolactin and oestradiol, but not oestradiol alone. Calcium $(P<0.05)$, chloride $(P<0.05)$ and potassium $(P<0.01)$ were increased in response to oestradiol. These results indicate an interaction between oestradiol and prolactin, but not progesterone and prolactin, which enhances secretion of some products of the pig uterine endometrium.
\end{abstract}

Keywords: prolactin; endometrium; secretion; pig; pregnancy

\section{Introduction}

Prolactin, a diverse and multifunctional hormone, affects uterine function. Species in which decidualization occurs during placentation (rat, human) have a decidual source of prolactin that is structurally similar to pituitary prolactin, but is differentially regulated (Healy \& Hodgen, 1983). Receptors for prolactin have been detected in the endometrium of humans (Healy, 1984), rats

${ }^{*}$ Reprint requests to F. W. Bazer. 
(Williams et al., 1978), mink (Rose et al., 1983), rabbits, sheep (Posner et al., 1974) and pigs (DeHoff et al., 1986; Young \& Bazer, 1987). Changes in numbers of uterine receptors for prolactin are temporally associated with: (1) increases in the concentration of circulating oestrogens; (2) endometrial proliferation, induction of steroid receptors and protein secretion (Chilton \& Daniels, 1985); (3) epithelial ion transport (Rabee \& McCoshen, 1986); and (4) placental transport of water and fetal growth (Goldstein et al., 1980). These findings suggest that prolactin may be critical to the establishment of the optimal uterine environment for conceptus development.

The role(s) of prolactin and its interaction with ovarian steroids on uterine function during the critical period of establishment of pregnancy is of great interest. The agent primarily responsible for maternal recognition of pregnancy in pigs is oestrogen of conceptus origin (Bazer \& Thatcher, 1977). Secreted initially on Days 11 and 12 of pregnancy, conceptus oestrogens are luteostatic and stimulate events leading to the release of histotroph from endometrial epithelium into the uterine lumen (Geisert et al., 1982a) to nourish the conceptus until extensive placentation begins on Day 18. Intramuscular injection of oestradiol valerate on Day 11 of the oestrous cycle mimics the effects of the conceptus (Geisert et al., 1982b). Additionally, intravenous administration of oestradiol stimulates both rapid $(0 \cdot 5-1 \mathrm{~h})$ and protracted $(12-24 \mathrm{~h})$ uterine secretory responses (Young et al., 1987). Oestrogen may induce this biphasic uterine secretory response indirectly through stimulation of, interaction with or synergism with other mechanisms or factors not associated with the classical receptor-mediated effects of oestrogen (Jensen et al., 1968).

The pig has an epitheliochorial placenta which is non-invasive, hence there is no uterine decidual reaction or local prolactin production, and the placenta does not produce placental lactogen. Therefore, effects of prolactin from the pituitary on modulation of uterine function in pigs must be mediated through other mechanisms. The numbers of prolactin receptors increase between Days 15 and 30, remain constant from Days 30 to 45, decrease slightly by Day 60, reach maximal levels at Day 75 and then decrease dramatically to Day 90 of gestation in pigs (DeHoff et al., 1984). Endometrial receptors for prolactin were greatest when there were the greatest increases in allantoic fluid volume (Goldstein et al., 1980), maximal secretion of endometrial proteins (Basha et al., 1979) and rates of fetal growth (Knight et al., 1973). Despite chronically low circulating concentrations of prolactin, these results suggest roles for prolactin in pigs throughout pregnancy and fetal development and that changes in numbers of receptors for prolactin may be regulated by oestrogens.

The present studies determined whether prolactin affects uterine secretory activity during the period of establishment of pregnancy and examined interactions between prolactin and oestrogen and progesterone on endometrial secretory activity.

\section{Materials and Methods}

Animals. Crossbred gilts of similar age (7-9 months) and weight (110-120 kg) were used in all studies after experiencing at least 2 oestrous cycles of normal lengths (18-22 days). Using intact boars, gilts were observed for oestrus daily and the first day of behavioural oestrus was designated Day 0 . Gilts were mated when detected in oestrus (Day 0 ) and 12 and $24 \mathrm{~h}$ later in studies using pregnant pigs.

Surgical procedures. Uterine flushings were collected in $20 \mathrm{ml}$ double distilled water per uterine horn as described previously (Bazer et al., 1978). Flushing volumes were recorded and flushings were centrifuged at $10000 \mathrm{~g}$ for $15 \mathrm{~min}$ at $4^{\circ} \mathrm{C}$. Supernatants were collected and stored at $-20^{\circ} \mathrm{C}$ until analysed. Gilts used in studies of prolactin effects on progesterone-induced uterine secretory components in Exp. 4 were ovariectomized on Day 4 of the oestrous cycle. Gilts were anaesthetized, subjected to midventral laparotomy and the ovaries were exteriorized; all vessels were tied and the ovaries removed with minimal trauma to the uterus.

Catheterizations. On the assigned day, gilts were anaesthetized and fitted with indwelling jugular catheters (Ford \& Maurer, 1978) which were maintained patent with 200 i.u. heparin/ml saline solution. After surgery, gilts were housed individually until collection of the final blood sample and removal of the catheters.

Exogenous hormone administration. For chronic steroid treatment, gilts received $200 \mathrm{mg}$ progesterone (Sigma, St Louis, MO, USA) in $4 \mathrm{ml}$ corn oil:ethanol solution $(90: 10, \mathrm{v} / \mathrm{v})$. Control gilts received $4 \mathrm{ml}$ vehicle only. Acute steroid treatment consisted of $0.5 \mathrm{ml}(10 \mathrm{mg} / \mathrm{ml}$ ) oestradiol valerate (Squibb, Raritan, NJ, USA) or $0.5 \mathrm{ml}$ corn oil. Exogenous pig prolactin (USDA/B-1; gift from Dr Douglas Bolt, National Animal Hormone Program Director) was diluted 
in phosphate-buffered saline (PBS; $1 \mathrm{mg} / \mathrm{ml} ; \mathrm{pH} 7 \cdot 2$ ), apportioned into $1.2 \mathrm{ml}$ volumes and stored at $4^{\circ} \mathrm{C}$ until injected subcutaneously.

Bromocriptine. Bromocriptine (a gift of Sandoz Pharmaceutical, East Hanover, NJ, USA), a dopamine agonist, was solubilized in absolute ethanol and mixed with saline $(1: 1, \mathrm{v} / \mathrm{v})$ to a concentration of $25 \mathrm{mg} / \mathrm{ml}$. Treated gilts received $100 \mathrm{mg}$ bromocriptine/day $(4 \mathrm{ml})$ subcutaneously while control gilts received $4 \mathrm{ml}$ vehicle solution on the basis of results of Kraeling et al. (1982).

Protein. Total recoverable protein concentrations in uterine flushings were determined by the method of Lowry et al. (1951) using bovine serum albumin as the standard.

Uteroferrin. Concentrations of uteroferrin in uterine flushings were determined by measurement of acid phosphatase activity (Scholsnagle et al., 1974; Basha et al., 1979). Values are expressed as $\mu$ mol $p$-nitrophenol phosphate (pNP) released per $\mathrm{ml}$ per $10 \mathrm{~min}$ at $\mathrm{pH} 4.9$ and $37^{\circ} \mathrm{C}$.

Calcium. The Calcette 4009 (Precision Systems, Inc., Sudbury, MA, USA) was used to determine calcium concentrations using ethylene glycol-bis- $N$ - $N^{\prime}$-tetraacetic acid (EGTA) for fluorometric titration of calcium in an aqueous solution (Alexander, 1971).

Chloride. Concentrations of chloride in uterine flushings were determined by a colorimetric assay, sensitive to 60 mequiv./l, adapted from Hamilton (1966).

Sodium and potassium. A flame photometer (Perkin Elmer 51Ca; Coleman Instruments Division, Oak Brook, IL, USA) was used to determine concentrations of sodium and potassium as described previously (Young \& Bazer, 1987).

Glucose. The Beckman Glucose Analyzer 2 (Beckman Instruments, Columbia, MD, USA) was used to determine glucose concentrations as a direct proportion to oxygen consumption (Bazer et al., 1984).

Leucine-acyl aminopeptidase. This membrane marker protein was used as an index of secretory activity and its concentration was determined using a colorimetric assay (Zavy et al., 1984). One Sigma Unit (SU) will release $1 \mu \mathrm{mol}$ $\left(143 \mu \mathrm{g}\right.$ ) of $\beta$-naphthylamine from L-leucine- $\beta$-naphthylamine per hour at $37^{\circ} \mathrm{C}$ and $\mathrm{pH} 7 \cdot 1$.

Prostaglandin ( $P G$ ) $F$. Uterine flushings were analysed for PGF by a radioimmunoassay (RIA) procedure described by Knickerbocker et al. (1986), using the antibody characterized by Kennedy (1985) and tritiated PGF-2 $\alpha$ ([5,6,8,9,11,12,14,15- $\left.{ }^{3} \mathrm{H}\right] \mathrm{PGF}-2 \alpha$; sp. act. $160-180 \mathrm{Ci} / \mathrm{mmol}$; Amersham Corporation, Arlington Heights, IL, USA). Standard curves were prepared in charcoal-stripped uterine flushings with known amounts of radioinert PGF-2 $\alpha$. A 1:5000 dilution of antiserum enabled detection of $10 \mathrm{pg}$ PGF/tube. Cross-reactivities of PGF- $2 \alpha$ antiserum with other prostaglandins were: $94 \%$ for PGF- $1 \alpha ; 2.4 \%$ for PGE-2; and $<0.1 \%$ for 13,14-dihydro-15-keto-PGF-2 $\alpha$, PGE and arachidonic acid. Inter- and intra-assay coefficients of variation were $14 \cdot 1 \%$ and $15 \cdot 7 \%$, respectively.

Prostaglandin E. Concentrations of PGE-2 in uterine flushings were determined using an assay similar to that described for PGF with a modification (Lewis et al., 1978) using tritiated PGE-2 $\left(\left[5,6,8,11,12,14,15-{ }^{3} \mathrm{H}\right] \mathrm{PGE}\right.$; sp. act. $140-170 \mathrm{Ci} / \mathrm{mmol}$; Amersham). A 1:6000 dilution of antiserum (Eli Lilly, Indianapolis, IN, USA) enabled detection of $5 \mathrm{pg}$ PGE-2/tube as different from zero. Cross-reactivities of PGE antiserum with other prostaglandins were; $24 \%$ for PGE; $1.7 \%$ for PGF-2 $\alpha$; $0.1 \%$ for 13,14-dihydro-15-keto-PGF-2 $\alpha$, PGF-1 $\alpha$ and arachidonic acid. Inter- and intra-assay coefficients of variation were $9 \cdot 7$ and $12 \cdot 4 \%$, respectively.

Prolactin. Concentrations of prolactin in serum were measured by a radioimmunoassay (RIA) sensitive to $1 \mathrm{ng} / \mathrm{ml}$ (Kraeling et al., 1982). The inter- and intra-assay coefficients of variation were 15.2 and $16.3 \%$, respectively.

Experiment 1. This experiment determined effects of hypoprolactinaemia on conceptus survival. Gilts were mated on Days 0 and 1 of the oestrous cycle and assigned randomly, 5 per treatment group, to receive either bromocriptine ( $100 \mathrm{mg} /$ day) or vehicle ( $4 \mathrm{ml} /$ day) once daily on Days 10-16 of gestation. Jugular vein blood samples were collected on Days 10 (preinjection), 15 (during injection) and 20 (4 days postinjection) using a vacutainer single-sample collection method to avoid prolonged stress. Serum was assayed for concentrations of prolactin. On Day 25 of gestation, gilts were injected with sodium thiamylal ( $1 \mathrm{~g}$, i.v.) to induce anaesthesia, which was then maintained with halothane using a closed-circuit unit, and subjected to midventral laparotomy. The uterus was exposed and examined for evidence of normal pregnancy. Each gilt received $15 \mathrm{mg}$ PGF-2a (Lutalyse, Upjohn Company, Kalamazoo, MI, USA) to terminate the pregnancy.

Experiment 2. This experiment was to determine effects of hypoprolactinaemia on uterine secretory activity. The protocol was to mimic effects of oestrogens from conceptuses on endometrial secretory activity during the time of maternal recognition of pregnancy without interactions with other conceptus products (Geisert et al., 1982a). After two normal oestrous cycles, the 10 gilts used in Exp. 1 were assigned randomly, 5 per treatment group, to receive either bromocriptine ( $100 \mathrm{mg} /$ day) or vehicle $(4 \mathrm{ml} /$ day) on Days 10 and 11 of the oestrous cycle. All gilts then received $5 \mathrm{mg}$ oestradiol valerate (i.m.) on Day 11. On Day 12, uterine flushings and a jugular vein blood sample were collected.

Experiment 3. This study was conducted to establish hyperprolactinaemia and avoid compromising results in Exps 4 and 5 due to confinement and chronic bleeding of the gilts. Non-pregnant gilts, 3 per treatment group, were assigned randomly to receive pig prolactin $(1 \mathrm{mg})$ or vehicle ( $1 \mathrm{ml}$ saline). On Day 7 , gilts were anaesthetized and fitted with 
indwelling jugular vein catheters. Jugular vein blood $(7 \mathrm{ml})$ samples were collected on Days 10 through 13 of the oestrous cycle at $07: 30,10: 00,12: 00,19: 30$ and $24: 00 \mathrm{~h}$. Prolactin or saline was administered subcutaneously at 08:00 and 20:00 h, $30 \mathrm{~min}$ after the morning and evening blood samples, on Days 10 through 14. Blood samples were assayed for concentration of prolactin in serum.

Experiment 4. This experiment investigated the interaction between prolactin and progesterone in the absence of oestrogens of ovarian origin. Ovariectomized pigs secrete uterine proteins as do ovary-intact gilts on Day 15 of the oestrous cycle or pregnancy when treated with an optimal dose $(200 \mathrm{mg} / \mathrm{ml})$ of progesterone alone (Knight et al., 1974). Non-pregnant gilts were ovariectomized on Day 4 of the oestrous cycle and injected with $200 \mathrm{mg}$ progesterone once daily from Days 4 to 14 . Gilts were assigned randomly to receive prolactin $(\mathrm{N}=4 ; 1 \mathrm{mg})$ or vehicle $(\mathrm{N}=3 ; 1 \mathrm{ml}$ saline) daily at 08:00 and 20:00 h on Days 4-14. Uterine flushings were collected on Day 15.

Experiment 5. This experiment determined effects of the interaction between oestrogen and prolactin using the protocol designed to mimic the effect of oestrogens of conceptus origin without confounding effects of other conceptus secretory products (Geisert et al., 1982a). Non-pregnant gilts, 4 per treatment group, were assigned randomly to receive one of three treatments. Gilts in the negative control group (corn oil only on Day 11) and positive control group ( $5 \mathrm{mg}$ oestradiol valerate in corn oil on Day 11 ) received $1 \mathrm{ml}$ saline twice daily at 07:30 and 19:30 $\mathrm{h}$ on Days 6 through 11 . Gilts in the treatment group received $1 \mathrm{mg}$ pig prolactin in saline twice daily at $07: 30$ and $19: 30 \mathrm{~h}$ and $5 \mathrm{mg}$ oestradiol valerate on Day 11. Uterine flushings were collected on Day 12, approximately $24 \mathrm{~h}$ after treatment with corn oil or oestradiol. A prolactin and corn oil treatment group was not included because results of Exp. 4 indicated no interaction between prolactin and progesterone on uterine secretory activity.

Statistics. Data were analysed by least squares analysis of variance using the General Linear Models procedures of the Statistical Analysis System (SAS) (Barr et al., 1979) to detect effects of treatment. When appropriate, orthogonal contrasts were used to detect differences between means.

\section{Results}

\section{Effects of hypoprolactinaemia}

Administration of bromocriptine to pregnant gilts (Exp. 1) decreased circulating concentrations of prolactin by $40 \%(P<0.06)$ on Day 15 . Prolactin levels $( \pm 0.33 \mathrm{ng} / \mathrm{ml})$ were $5.0,3.3 \mathrm{and} 4.4 \mathrm{ng} /$ $\mathrm{ml}$ and $5 \cdot 2,5 \cdot 0$ and $4 \cdot 4 \mathrm{ng} / \mathrm{ml}$ on Days 10,15 and 20 of gestation for gilts that received bromocriptine and vehicle only, respectively. The number of corpora lutea (CL) was not different on Day 25 of gestation between gilts that received bromocriptine $(13.6 \pm 0.9)$ and vehicle $(14.0 \pm 0.9)$ and litter size was similar between gilts that received bromocriptine $(7 \cdot 3 \pm 1 \cdot 75)$ and vehicle $(8 \cdot 4 \pm 1 \cdot 75)$.

Administration of bromocriptine to cyclic gilts (Exp. 2) decreased circulating concentrations of prolactin by $50 \%(2.7 \pm 0.33 \mathrm{ng} / \mathrm{ml} v s 5.3 \pm 0.33 \mathrm{ng} / \mathrm{ml} ; P<0.06)$ on Day 12 to levels that were similar to those reported for bromocriptine-treated pigs by Kraeling et al. (1982), Whitacre \& Threlfall (1981) and Smith \& Wagner (1985). The inability to suppress circulating prolactin totally in pigs may be due to its regulation by factors other than dopamine. Previously reported dosages of $480 \mathrm{mg} /$ day did not affect prolactin support of corpus luteum function in mid-gestation of pigs (R. R. Kraeling, cited by Bazer \& First, 1983). Total recoverable protein (mg), uteroferrin ( $\mu \mathrm{mol})$, and glucose $(\mathrm{mg})$ concentrations, respectively, were not different in uterine flushings from gilts that received bromocriptine $(17.6 \pm 2.4 \mathrm{mg} ; 541 \pm 92 \mu \mathrm{mol}$ and $2.23 \pm 0.13 \mathrm{mg}$ ) compared to those that received vehicle $(19.2 \pm 2.4 \mathrm{mg} ; 608 \pm 92 \mu \mathrm{mol}$ and $2.35 \pm 0.13 \mathrm{mg})$. However, concentrations of leucine aminopeptidase were lower $(P<0.025)$ in uterine flushings of bromocriptine$(140 \pm 18 \mathrm{SU})$ compared to vehicle- $(230 \pm 18 \mathrm{SU})$ treated gilts. Concentrations of PGF $(30 \pm 5 \mathrm{vs}$ $17 \pm 5 \mathrm{ng} /$ horn$)$ and PGE (14 $\pm 2 \cdot 2$ vs $11 \pm 2 \cdot 2 \mathrm{ng} /$ horn $)$ in uterine flushings were not affected by treatment. Gilts that received bromocriptine had lower concentrations of calcium $(P<0.03)$, sodium $(P<0.02)$, potassium $(P<0.01)$ and chloride $(P<0.01)$ in uterine flushings (Fig. 1$)$.

\section{Experiment 3}

Effects of administration of exogenous prolactin are presented in Fig. 2. Concentrations of prolactin in serum increased within $2 \mathrm{~h}$ in gilts that received exogenous pig prolactin. Over the 4 

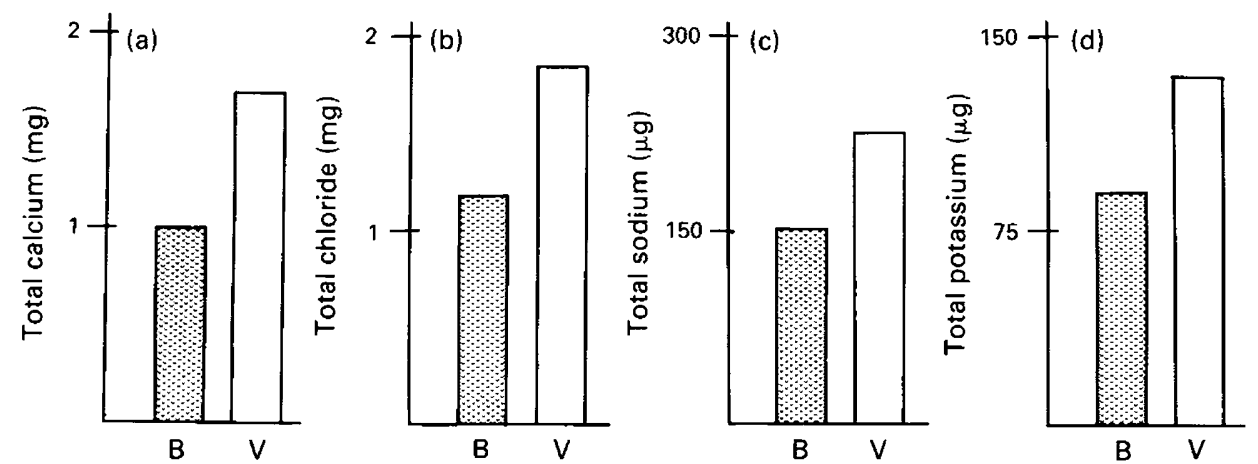

Fig. 1. Concentrations of total recoverable calcium (a), chloride (b), sodium (c) and potassium (d) in uterine flushings from Day 12 cyclic gilts (Exp. 2) treated with bromocriptine (100 mg/ day; B) or vehicle $(4 \mathrm{ml}, \mathrm{V})$ on Days 10 and 11 and oestradiol valerate on Day 11 . Treatment effects were detected for calcium and potassium $(P<0.05)$, as well as sodium and chloride $(P<0 \cdot 01)$. The s.e.m. was $\pm 0 \cdot 14$ for calcium, $\pm 0 \cdot 12$ for chloride, \pm 12 for sodium and \pm 8 for potassium.

days of administration, concentrations of prolactin were $4 \cdot 5$-fold higher $(P<0.001)$ for gilts that received prolactin $(19.6 \pm 1.2 \mathrm{ng} / \mathrm{ml})$ compared to control gilts $(4.25 \pm 0.13 \mathrm{ng} / \mathrm{ml})$. Although serum concentrations of prolactin were higher than those for control gilts, they were not pharmacological since concentrations of prolactin in serum of pigs during oestrus and late luteal phase are 15-20 ng/ml (Brinkley et al., 1973; Dusza \& Kryzmowska, 1979).

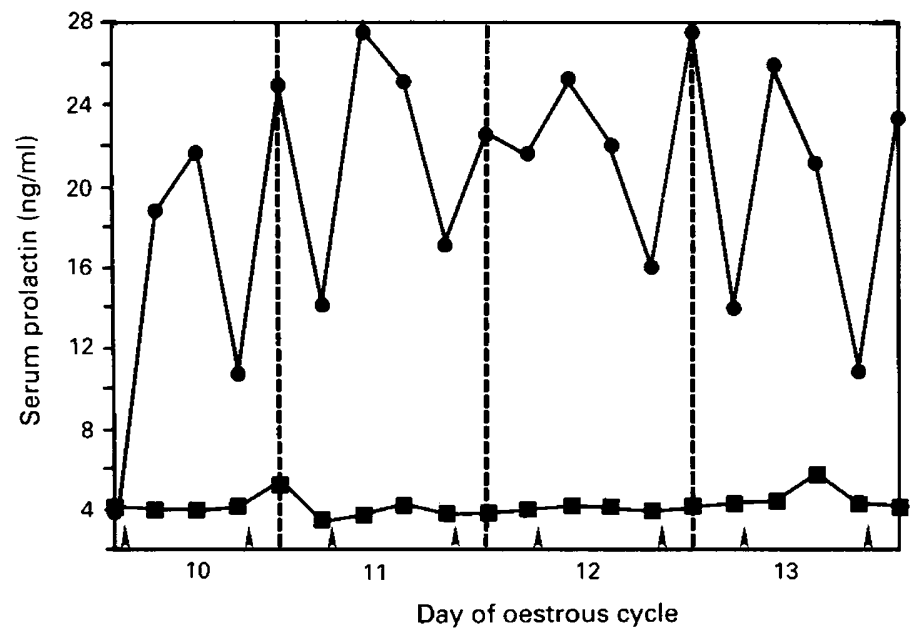

Fig. 2. Concentrations of circulating immunoreactive prolactin during administration of $1 \mathrm{mg}$ pig prolactin (on Days 10-13 of the oestrous cycle. Blood samples were collected at 07:30, 10:00, 12:00, 19:30 and $24: 00 \mathrm{~h}$. The s.e.m. were $\pm 1.2 \mathrm{ng} / \mathrm{ml}$ for pig prolactin- and $\pm 0.13 \mathrm{ng} / \mathrm{ml}$ for saline-treated gilts.

\section{Experiment 4}

Exogenous administration of prolactin did not significantly affect any of the progesteroneinduced uterine secretory components examined in the uterine flushings (Table 1). 
Table 1. Composition of Day 15 uterine flushings from ovariectomized gilts treated with daily injections of progesterone and saline or pig prolactin from Days 4 to 14

\begin{tabular}{lcc}
\hline & Saline & Prolactin \\
\hline Total protein (mg) & $74 \cdot 3 \pm 19 \cdot 3$ & $74 \cdot 0 \pm 16 \cdot 7$ \\
Total uteroferrin* & $4138 \pm 1903$ & $4230 \pm 1648$ \\
$\quad(\mu$ mol/uterine horn) & $45 \cdot 7 \pm 14 \cdot 9$ & $51 \cdot 7 \pm 13 \cdot 0$ \\
Uteroferrin/mg protein & $0 \cdot 5 \pm 0 \cdot 2$ & $0 \cdot 4 \pm 0 \cdot 2$ \\
Total calcium (mg) & $1 \cdot 7 \pm 0 \cdot 3$ & $1 \cdot 5 \pm 0 \cdot 2$ \\
Total chloride (mg) & $125 \cdot 3 \pm 32 \cdot 1$ & $93 \cdot 5 \pm 27 \cdot 9$ \\
Total sodium $(\mu \mathrm{g})$ & $170 \cdot 2 \pm 46 \cdot 7$ & $131 \cdot 8 \pm 40 \cdot 4$ \\
Total potassium $(\mu \mathrm{g})$ & $2 \cdot 5 \pm \mathbf{0} \cdot 3$ & $2 \cdot 8 \pm 0 \cdot 3$ \\
Total glucose $(\mathrm{mg})$ & $655 \pm 112$ & $604 \pm 92$ \\
Total L-acyl aminopeptidase $\dagger$ & $235 \pm 22$ & $219 \pm 19$ \\
Total PGF (ng/uterine horn) & $38 \cdot 6 \pm 6 \cdot 7$ & $34.6 \pm 5 \cdot 8$ \\
Total PGE (ng/uterine horn) & &
\end{tabular}

Values are mean \pm s.e.m.

${ }^{*}$ Activity $=\mu \mathrm{mol} p$-nitrophenol released $/ \mathrm{ml} / 10 \mathrm{~min}$ at $37^{\circ} \mathrm{C}$.

†Sigma Units: 1 Sigma Unit will release $1 \mu \mathrm{mol}(143 \mu \mathrm{g}) \beta$-naphthylamine from L-leucine- $\beta$-naphthylamine/h at $37^{\circ} \mathrm{C}, \mathrm{pH} 7 \cdot 1$.

\section{Experiment 5}

Effects of exogenous prolactin on oestrogen-induced uterine secretory activity are summarized in Table 2. Treatment effects were detected for total recoverable protein and total uteroferrin $(P<0.001)$, total glucose $(P<0.01)$, total leucine aminopeptidase $(P<0.05)$, total calcium $(P<0.03)$, total chloride $(P<0.02)$, total potassium $(P<0.01)$ and total PGF $(P<0.02)$ in uterine flushings. There was no effect of treatment on sodium or PGE in uterine flushings. Additionally, gilts treated with prolactin and oestradiol had greater amounts of uteroferrin $(P<0.01)$, glucose $(P<0.01)$ and PGF $(P<0.01)$ in uterine flushings than did gilts receiving oestradiol alone. However, values for glucose and PGF were not different for gilts treated on Day 11 with oestradiol or corn oil. The specific activity of uteroferrin $(\mu \mathrm{mol} / \mathrm{mg}$ protein) was higher $(P<0.01)$ in uterine flushings from gilts treated with prolactin and oestradiol $(106 \cdot 53 \pm 9 \cdot 3)$ when compared to gilts receiving oestradiol $(56 \cdot 68 \pm 9 \cdot 3)$ or corn oil $(8 \cdot 36 \pm 9 \cdot 3)$. Gilts receiving oestradiol and prolactin had greater uterine secretory responses for total protein, potassium and aminopeptidase compared to gilts receiving oestradiol alone, but differences were not statistically significant.

\section{Discussion}

The results from the present experiments suggest that, within the pig uterus, prolactin affects the ionic environment of the developing conceptus. Prolactin influences ion and water fluxes in mammary alveolae (Falconer \& Rowe, 1977) and intestine (Riddle, 1963; Mainoya et al., 1974). In this study, slight hypoprolactinaemia decreased concentrations of $\mathrm{Ca}^{2+}, \mathrm{Na}^{+}, \mathrm{K}^{+}$, and $\mathrm{Cl}^{-}$ions in uterine flushings, but did not affect total protein. The inability of lowered prolactin concentrations to alter secretion of proteins may be due to lack of effects on ion ratios despite lowered individual ion levels. The effects of decreasing concentrations of ions may not have occurred in a temporal pattern necessary to result in a change in the secretion of proteins. The aminopeptidase activity in uterine flushings was decreased in response to hypoprolactinaemia suggesting a decrease in secretory activity of endometrial epithelium (Zavy et al., 1984). Additionally, the decrease in circulating prolactin levels in the present study may have been compensated for physiologically through other mechanisms, e.g. an increase in prolactin receptor numbers, as has been previously 
Table 2. Composition of Day 12 uterine flushings from cyclic gilts treated with twice daily injections of saline or pig prolactin from Days 6 to 11 and corn oil or oestradiol valerate on Day 11 of the oestrous cycle

\begin{tabular}{|c|c|c|c|c|}
\hline \multirow[b]{2}{*}{ Value/uterine horn } & \multicolumn{4}{|c|}{ Treatment } \\
\hline & $\begin{array}{c}\text { Saline } \\
+ \\
\text { corn oil }\end{array}$ & $\begin{array}{c}\text { Prolactin } \\
+ \\
\text { oestradiol } \\
\text { valerate }\end{array}$ & $\begin{array}{c}\text { Saline } \\
+ \\
\text { oestradiol } \\
\text { valerate }\end{array}$ & s.e.m. \\
\hline Protein (mg) & $14 \cdot 2^{a}$ & $36 \cdot 1^{b}$ & $31 \cdot 7^{b}$ & $\pm 2 \cdot 7$ \\
\hline Uteroferrin * $(\mu \mathrm{mol})$ & $125 \cdot 6^{\mathrm{a}}$ & $3709 \cdot 5^{\mathrm{b}}$ & $1811 \cdot 2^{\mathrm{c}}$ & $\pm \overline{278} \cdot 3$ \\
\hline Uteroferrin/mg protein & $8 \cdot 6^{\mathrm{a}}$ & $106 \cdot 5^{\mathrm{a}}$ & $56 \cdot 7^{\mathrm{c}}$ & \pm 9.3 \\
\hline Calcium (mg) & $0 \cdot 4^{\mathrm{a}}$ & $1 \cdot 2^{b}$ & $1 \cdot 5^{b}$ & $\pm 0 \cdot 3$ \\
\hline Chloride (mg) & $0 \cdot 7^{\mathrm{a}}$ & $1 \cdot 4^{b}$ & $1 \cdot 5^{b}$ & \pm 0.2 \\
\hline Sodium $(\mu \mathrm{g})$ & $58 \cdot 7^{a}$ & $74 \cdot 1^{\mathrm{a}}$ & $74 \cdot 4^{\mathrm{a}}$ & $\pm 17 \cdot 4$ \\
\hline Potassium $(\mu \mathrm{g})$ & $54 \cdot 0^{\mathrm{a}}$ & $99 \cdot 3^{b}$ & $73.9^{b}$ & $\pm 9 \cdot 3$ \\
\hline Leucine aminopeptidase $\dagger$ & $195 \cdot 2^{\mathrm{a}}$ & $365 \cdot 6^{b}$ & $280 \cdot 0^{\mathrm{b}}$ & $\pm 52 \cdot 7$ \\
\hline Glucose (mg) & $1 \cdot 5^{a}$ & $2 \cdot 4^{\mathrm{b}}$ & $1 \cdot 5^{\mathrm{a}}$ & $\pm 0 \cdot 2$ \\
\hline PGE (ng) & $26 \cdot 7^{a}$ & $27 \cdot 1^{a}$ & $26 \cdot 5^{a}$ & $\pm 6 \cdot 7$ \\
\hline PGF (ng) & $7 \cdot 8^{a}$ & $46 \cdot 6^{\mathrm{b}}$ & $5 \cdot 9^{a}$ & $\pm 10 \cdot 2$ \\
\hline
\end{tabular}

Values are mean \pm s.e.m.

${ }^{a b c}$ Values within rows with different letters are significantly different $(P<0.05$ for calcium and leucine aminopeptidase; $P<0.01$ for protein, uteroferrin, chloride, potassium, glucose and PGF).

*Activity $=\mu \mathrm{mol} p$-nitrophenol released $/ \mathrm{ml} / 10 \mathrm{~min}$ at $37^{\circ} \mathrm{C}$.

tOne Sigma Unit will release $1 \mu \mathrm{mol}(143 \mu \mathrm{g}) \beta$-naphthylamine from $L$-leucine $\beta$-naphthylamine $/ \mathrm{h}$ at $37^{\circ} \mathrm{C} \mathrm{pH} 7 \cdot 1$.

demonstrated for rabbit mammary tissue (Djiane et al., 1977) and rat liver (Kelly et al., 1979), or hormonal regulation at the central nervous system, receptor levels in the hypothalamus and target tissue (Muldoon, 1987) or by interpituitary communication (Murai et al., 1988). Prolactin may stimulate the release of extracellular mediators from the liver, such as synlactin (Mick \& Nicoll, 1985) or liver lactogenic factor (Hoeffler \& Frawley, 1987) which act synergistically or additively with prolactin, respectively, at the target organ. Lastly, effects of prolactin may be regulated by intracellular enzymes that cleave the secreted prolactin to lower molecular weight subunits $\left(M_{\mathrm{r}}\right.$ 16000 ) (Nolin, 1982; Clapp, 1987; Vick et al., 1987) that have specific intracellular effects. Since serum concentrations of prolactin do not change significantly over the period of maternal recognition of pregnancy in pigs, several of these factors may interact to potentiate the effect of prolactin on uterine secretory epithelium. In particular, oestrogen may regulate prolactin receptor numbers in target tissues.

Exogenous prolactin interacted with oestrogen, but not progesterone, to cause significant effects on uterine epithelial secretory activity. Shifts in concentrations of ions could account for the earlier release of several uterine secretory components; although such shifts could not be accounted for by static measurements on Day 12 in the present study. These effects, and those on PG, are probably due to prolactin and not contamination by other pituitary hormones. Pig prolactin is extensively dialysed during purification and contains $<1 \%$ of the other anterior pituitary hormones; contamination by vasopressin or oxytocin is even less likely. Prolactin influences ion and water fluxes in the intestine (Mainoya et al., 1974) and mammary alveolar cells (Falconer \& Rowe, 1977).

Shifts in ions occur before protein secretion during early pregnancy (Geisert $e$ t al., 1982a; Bazer et al., 1984) and in response to administration of exogenous oestradiol on Day 11. With respect to the secretory profiles of uterine components in the experiments reported here, exogenous prolactin may have advanced the rapid release and reuptake of calcium which characteristically follows 
oestrogen stimulation and precedes accumulation of proteins in the uterine lumen. Luminal calcium flux may have occurred early on Day 11 in hyperprolactinaemic gilts. Therefore, calcium measured in uterine flushings on Day 12 could be influenced by advanced calcium reuptake that does not normally occur until Days 13-14 of pregnancy. This may account for the increase in glucose and uteroferrin on Day 12 for prolactin-treated pigs compared to previous reports that glucose and uteroferrin concentrations do not increase until Days 14-16 during a normal pregnancy. Hyperprolactinaemia resulted in increased concentrations and specific activity of uteroferrin in (Day 12) uterine flushings. Increases in this protein usually occur on Day 14 of gestation (Zavy et al., 1982). Since there was not a concomitant increase in aminopeptidase, a membrane marker protein indicative of secretory activity, prolactin may have altered uteroferrin synthesis resulting in increased amounts stored within intracellular secretory granules and available for release after oestrogen stimulation. Additionally, hyperprolactinaemia resulted in increased concentration of glucose in uterine flushings on Day 12 which normally does not occur until Days 14-16 of pregnancy (Zavy et al., 1984). Administration of prolactin appeared to advance the ability of uterine epithelium to respond to oestrogen-induced secretory activity.

Stimulation of secretion of prostaglandins of the $F$, but not the E, series suggests that effects of prolactin may be on the uterine epithelium since PGF and PGE secretion has been localized to the endometrial epithelium and stroma, respectively, of cows (Grasso et al., 1987). Prolactin exerts luteostatic effects in several species (Murphy \& Rajkumar, 1985), primarily through stimulation of ovarian steroid production. Prolactin appears to advance the ability of the uterus to respond to oestradiol since an increase in luminal PGF occurred 48-72 $\mathrm{h}$ after a single injection of oestradiol valerate to Day-11 cyclic gilts (Geisert et al., 1982a). During establishment of pregnancy in the pig, PGF secretion must be redirected from an endocrine to an exocrine direction (Bazer $\&$ Thatcher, 1977 ) to protect the corpus luteum from regression. The ability of prolactin to stimulate secretion of PGF and enhance its secretion into the uterine lumen (Mirando et al., 1988) is a novel finding suggesting that prolactin plays a luteostatic role, in conjunction with oestrogen, in early pregnancy of pigs.

The present findings in the pig support the hypothesis that prolactin modulates uterine secretory activity during establishment of pregnancy as previously described for the long-term ovariectomized rabbit (Chilton \& Daniels, 1985). Prolactin increased uterine secretory function and caused differential changes in ions, increased secretion of proteins, PGF and glucose. Although the mechanism(s) by which prolactin influences the endometrial secretory profile is not known, the effects may occur through several mechanisms. Previously reported effects include: (1) activation of ion channels to facilitate transport and secretion of cellular components (Petersen \& Maruyama, 1985 ) or stimulation of membrane cycling of calcium (Alkon \& Rasmussin, 1988); (2) increased oestrogen binding by cells of rat liver (Chamness et al., 1975) and uterus (Leung \& Sasaki, 1973); (3) facilitation of the formation of gap junctions to increase intercellular communication (Sorenson et al., 1987), and (4) up-regulation of prolactin receptors to increase membrane fluidity (Dave \& Witorsch, 1985) and increase the availability of cryptic hormone receptors, e.g. Dave et al. (1983) observed an increase in prolactin binding during early pregnancy which they attributed to alterations in membrane fluidity.

During the time of maternal recognition of pregnancy in the pig, prolactin interacts with oestrogen, rather than progesterone, to influence uterine endometrial secretory activity. This selective interaction with oestrogen may allow the uterine endometrium to respond maximally to the oestrogen signal from the pig conceptus which allows establishment of pregnancy.

This manuscript is published as Journal Series No. 9314, University of Florida, Agricultural Experiment Station. This research was supported, in part, by U.S.D.A. Grant CRCR-86-1-2106. We thank Dr Douglas Bolt, U.S.D.A. Animal Hormone Program Director, for providing the pig prolactin used in these studies; and Ms Filomina Fliss for conducting the prostaglandin assays. 


\section{References}

Alexander, R.L. (1971) Evaluation of an automatic calcium titrator. Clin. Chem. 17, 1171-1175.

Alkon, D.L. \& Rasmussin, H. (1988) A spatial-temporal model of cell activation. Science, N.Y. 239, 998-1005.

Barr, A.J., Goodnight, J.H., Sall, J.P., Blair, W.H. \& Chulko, D.M. (1979) SAS User's Guide, SAS Institute, Raleigh.

Basha, S.M.M., Bazer, F.W. \& Roberts, R.M. (1979) The secretion of a uterine specific purple acid phosphatase by cultured explants of porcine endometrium: dependency upon the state of pregnancy of the donor animal. Biol. Reprod. 20, 431-442.

Bazer, F.W. \& First, N.L. (1983) Pregnancy and parturition. J. Anim. Sci. 57 (Suppl. 2), 425-460.

Bazer, F.W. \& Thatcher, W.W. (1977) Theory of maternal recognition of pregnancy in swine based on estrogen controlled endocrine versus exocrine secretion of prostaglandin $F_{2}$ by the uterine endometrium. Prostaglandins 14, 397-400.

Bazer, F.W., Roberts, R.M. \& Sharp, D.C. (1978) Collection and analysis of female genital tract secretions. In Methods in Mammalian Reproduction, pp. 503-527. Ed. J. C. Daniels. Academic Press, New York.

Bazer, F.W., Roberts, R.M., Mejia, A.M., Clark, W.R. \& Vallet, J.V. (1984) Protein, electrolytes and glucose in uterine flushings of pregnant and nonpregnant gilts. Biol. Reprod. (Suppl. 1), 30, 192, abstr.

Brinkley, H.J., Wilfinger, W.W. \& Young, E.P. (1973) Plasma prolactin in the estrous cycle of the pig. $J$. Anim. Sci. 37, 303, abstr.

Chamness, G.C., Costlow, M.E. \& McGuire, W.L. (1975) Estrogen receptor in rat liver and its dependence on prolactin. Steroids 26, 363-371.

Chilton, B.S. \& Daniels, J.C. (1985) Influence of prolactin on DNA synthesis and glandular differentiation in rabbit uterine endometrium. In Prolactin, Basic and Clinical Correlates, pp. 351-359. Eds R. M. MacLeod, M. O. Thorner \& U. Scapagini. Fidia Research Series, Springer-Verlag, Berlin.

Clapp, C. (1987) Analysis of the proteolytic cleavage of prolactin by the mammary gland and liver of the rat: characterization of the cleaved and $16 \mathrm{~K}$ forms. Endocrinology 121, 2055-2064.

Dave, J.R. \& Witorsch, R.J. (1985) Prolactin increases lipid fluidity and prolactin binding of rat prostatic membranes. Am. J. Physiol. 248, E687-693.

Dave, J.R., Richardson, L.L. \& Knazek, R.A. (1983) Prolactin-binding capacity, prostaglandin synthesis and fluidity of murine hepatic membranes are modified during pregnancy and lactation. J. Endocr. 99, 99-106.

DeHofi, M.H., Bazer, F.W. \& Collier, R.J. (1984) Ontogeny of prolactin receptors in porcine uterine endometrium during pregnancy. Proc. 4 th Int. Prolactin Congr., Quebec, p. 95, abstr.

DeHoff, M.H., Stoner, C.S., Bazer, F.W., Collier, R.J., Kraeling, R.R. \& Buonomo, F.C. (1986) Temporal changes in steroids, prolactin and growth hormone in pregnancy and pseudopregnancy in gilts during mammogenesis and lactogenesis. Dom. Anim. Endocr. 3, 95-105.
Djiane, J., Durand, P. \& Kelly, P.A. (1977) Evolution of prolactin receptors in rabbit mammary gland during pregnancy and lactation. Endocrinology 100, $1348-1356$.

Dusza, L. \& Kryzmowska, H. (1979) Plasma prolactin concentrations during the oestrous cycle of sows. $J$. Reprod. Fert. 57, 511-514.

Falconer, I.R. \& Rowe, J.M. (1977) Effect of prolactin on sodium and potassium concentrations in mammary alveolar tissue. Endocrinology 101, 181-186.

Ford, J.J. \& Maurer, R.R. (1978) Simple technique for chronic venous catheterization of swine. Lab. Anim. Sci. 28, 615-618.

Geisert, R.D., Reneger, R.H., Thatcher, W.W., Roberts, R.M. \& Bazer, F.W. (1982a) Establishment of pregnancy in the pig. I. Interrelationships between preimplantation development of the pig blastocyst and uterine endometrial secretions. Biol. Reprod. 27, 925949.

Geisert, R.D., Thatcher, W.W., Roberts, R.M. \& Bazer, F.W. (1982b) Establishment of pregnancy in the pig. II. Endometrial secretory response to oestradiol valerate administered on Day 11 of the estrous cycle. Biol. Reprod. 27, 957-965.

Goldstein, M.H., Bazer, F.W. \& Barron, D.H. (1980) Characteristics of changes in volume, osmolarity and electrolyte composition of porcine fetal fluids during gestation. Biol. Reprod. 22, 1168-1 180.

Grasso, F., Guilbault, L.A. \& Fortier, M.A. (1987) Prostaglandin production by cultured and epithelial cells of the bovine endometrium: influence of steroids. $J$. Anim. Sci. (Suppl.) 65, 412, abstr.

Hamilton, R.H. (1966) A direct photometric method for chloride in biological fluids employing mercuric thiocyanate and perchloric acid. Clin. Chem. 12, 117.

Healy, D.L. (1984) The clinical significance of endometrial prolactin. Aust. N.Z. Jl Obstet. Gynaecol. 24, 111-116.

Healy, D.L. \& Hodgen, G.D. (1983) The endocrinology of human endometrium. Obstet. Gynecol. Surv. 38, $509-530$.

Hoeffler, J.P. \& Frawley, L.S. (1987) Liver tissue produces a potent lactogen that partially mimics the actions of prolactin. Endocrinology 120, 1679-1681.

Jensen, E.V., Suzuki, T., Kawashima, T., Stumpf, W.E., Jungblut, P.W. \& DeSombre, E.R. (1968) A two step mechanism for the interaction of estradiol and the rat uterus. Proc. natn. Acad. Sci. USA 59, 632-638.

Kelly, P.A., LeBlanc, G. \& Djiane, J. (1979) Estimation of total prolactin-binding sites after in vitro desaturation. Endocrinology 104, 1631-1638.

Kennedy, T.G. (1985) Evidence for the involvement of prostaglandins throughout the decidual cell reaction in the rat. Biol. Reprod. 33, 140-146.

Knickerbocker, J.J., Thatcher, W.W., Foster, D.B., Wolfensen, D., Bartol, F.F. \& Caton, D. (1986) Uterine prostaglandin and blood flow responses to estradiol$17 \beta$ in cyclic cattle. Prostaglandins 31, 757-776.

Knight, J.W., Bazer, F.W. \& Wallace, N.D. (1973) Hormonal regulation of porcine uterine protein secretion. J. Anim. Sci. 36, 546-553. 
Knight, J.W., Bazer, F.W., Wallace, H.D. \& Wilcox, C.J. (1974) Dose-response relationships between exogenous progesterone and estradiol and porcine uterine protein secretions. J. Anim. Sci. 39, 747-751.

Kraeling, R.R., Rampacek, G.B., Cox, N.M. \& Kriser, T.E. (1982) Prolactin and luteinizing hormone secretion after bromocriptine (CB-154) treatment on lactating sows and ovariectomized gilts. J. Anim. Sci. 54, 1212-1220.

Leung, B.S. \& Sasaki, G.H. (1973) Prolactin and progesterone effect in specific estadiol binding in uterine and mammary tissues in vitro. Biochem. Biophys. Res. Commun. 55, 1180-1187.

Lewis, G.S., Jenkins, P.E., Fogwell, R.L. \& Inskeep, K.E. (1978) Concentrations of prostaglandins $E_{2}$ and $F$ and their relationship to luteal function in early pregnant ewes. J. Anim. Sci. 47, 1314-1323.

Lowry, O.H., Rosebrough, N.J., Farr, A.L. \& Randall, R.J. (1951) Protein determination with the folin phenol reagent. J. biol. Chem. 193, 265-275.

Mainoya, J.R., Bern, H.A. \& Regan, J.W. (1974) Influence of ovine prolactin on transport of fluid and sodium chloride by mammalian intestine and gall bladder. J. Endocr. 63, 311-317.

Mick, C.C. \& Nicoll, C.S. (1985) Prolactin directly stimulates the liver in vivo to secrete a factor (Synlactin) which acts synergistically with the hormone. Endocrinology 116, 2049-2053.

Mirando, M.A., Gross, T.S., Young, K.H. \& Bazer, F.W. (1988) Reorientation of prostaglandin F (PGF) secretion by calcium ionophore, oestradiol and prolactin in perifused porcine endometrium. J. Reprod. Fert., Abstract Series 1, Abstr. 58.

Muldoon, T.G. (1987) Prolactin mediation of estrogeninduced changes in mammary tissue estrogen and progesterone receptors. Endocrinology 121, 141-149.

Murai, I., Garris, P.A. \& Ben-Jonathan, N. (1988) A time dependent increase in plasma prolactin after pituitary stalk section: role for stored posterior pituitary dopamine. Endocrinology 122 (Suppl.), 250, abstr.

Murphy, B.D. \& Rajkumar, K. (1985) Prolactin as a luteotrophin. Can. J. Physiol. Pharmacol. 63, 257264.

Nolin, J.M. (1982) Profiles of target-cell prolactin and adrenocorticotropin during lactational diestrus. In Reproductive Processes and Contraception, pp. 195213. Ed. K. W. McKerns. Plenum Press, New York.

Peterson, O.H. \& Maruyama, Y. (1985) Single-channel current recording from pancreatic acinar cells. In The Electrophysiology of the Secretory Cell, pp. 37-59. Eds A. M. Posner \& J. M. Trifaro. Elsevier Science Publications, New York.

Posner, B.I., Kelly, P.A., Shiu, R.P.C. \& Friesen, H.G. (1974) Studies on insulin, growth hormone, and prolactin binding: tissue distribution, species variation and characterization. Endocrinology 95, 521-531.
Rabee, M.A. \& McCoshen, J.A. (1986) Epithelial regulation of prolactin effect on amniotic permiability. Am. J. Obstet. Gynecol. 154, 130-134.

Riddle, O. (1963) Prolactin in vertebrate function and organization. J. natn. Cancer. Inst. 31, 1039-1109.

Rose, J., Stormshak, F., Adair, J. \& Oldfield, J.E. (1983) Prolactin binding sites in the uterus of the mink. Molec. cell. Endocr. 31, 131-139.

Scholsnagle, D.C., Bazer, F.W., Tsibris, J.C.M. \& Roberts, R.M. (1974) An iron-containing phosphate induced by progesterone in the uterine fluids of pigs. J. biol. Chem. 249, 7574-7579.

Smith, B.C. \& Wagner, W.C. (1985) Effect of dopamine agonist or antagonists, TRH, stress and piglet removal in plasma prolactin concentrations in lactating pigs. Theriogenology 23, 283-296.

Sorenson, R.L., Johnson, J.G., Parsons, J.A. \& Sheridan, J.D. (1987) Decreased glucose stimulation threshold, enhanced insulin secretion and increased beta cell coupling in prolactin treated rats: characteristics of islet function in pregnancy. Pancreas 2, 283-288.

Vick, R.S., Wong, V.L.Y. \& Witorsch, R.J. (1987) Biological, immunological and biochemical characterization of cleaved prolactin generated by the lactating mammary gland. Biochem. Biophys. Acta 931, 191204.

Whitacre, M.D. \& Threlfall, W.R. (1981) Effect of ergocriptine on plasma prolactin, luteinizing hormone and progesterone in the periparturient sow. Am. J. vet. Res. 42, 1538-1541.

Williams, G.H., Hammond, J.M., Weiss, J. \& Mortal, R. (1978) Binding sites for lactogenic hormone in the rat uterus. Biol. Reprod. 18, 697-706.

Young, K.H. \& Bazer, F.W. (1987) Development of a homologous radioreceptor assay (RRA) for porcine prolactin (pPRL). Biol. Reprod. 36 (Suppl. 1), 74, abstr.

Young, K.H., Bazer, F.W., Simpkins, J.W. \& Roberts, R.M. (1987) Effects of early pregnancy and acute $17 \beta$-estradiol administration on porcine uterine secretion, cyclic nucleotides, and catechaolamines. Endocrinology 120, 254-263.

Zavy, M.T., Clark, W.R., Sharp, D.C., Roberts, R.M. \& Bazer, F.W. (1982) Comparison of glucose, fructose, ascorbic acid and glucose phosphate isomerase enzymatic activities in uterine flushings from nonpregnant and pregnant gilts and pony mares. Biol. Reprod. 27, $1147-1158$.

Zavy, M.T., Roberts, R.M. \& Bazer, F.W. (1984) Acid phosphatase and leucine aminopeptidase activity in the uterine flushing of nonpregnant and pregnant gilts. J. Reprod. Fert. 72, 503-507.

Received 28 November 1988 